matters: (1) the height to which the mountains must have risen (supposing the mean temperature to have been the same as now) in order that they could have generated glaciers which would have come down to the sea; (2) whether in this case it is probable that granite would have been exposed at the surface; (3) whether it is probable (looking especially at the evidence of the breccias in the red rocks of Devon) that high mountains existed in this part of England during Cretaceous times. I may add that Mr. Stebbing, so far as 1 remember his excellent paper, never invoked a Glacial Epoch; that spectre was raised during the debate; nor is it necessary to create a glacier to transport the boulders. Shore-ice, such as forms in the estuary of the St. Lawrence, would be quite adequate for the work. If it started from some northern locality it might readily float down (as slab-ice still does in the Atlantic) well south of the latitude of London.

T. G. Bonney.

\title{
FOREIGN BOULDERS IN THE CHALK, AND GASES ENCLOSED IN CRYSTALLINE ROCKS.
}

SIR,-(1) Referring to Mr. G. A. Martin's interesting suggestion (Geol. MAG., April, 1897, p. 169) that the Betchworth boulder came from Dartmoor, and to its alleged similarity to the granites of Hey Tor and Lustleigh Cleave, the microscope would probably answer this question decisively. Within fifty niles of Hey Tor the floor of the English Channel is strewn with detached blocks of crystalline rocks. Of these blocks $I$ have a large collection of slides, and also a considerable number of specimens from all parts of Dartmoor; collected for the most part by myself, or sent me by the late Mr. R. N. Worth. Not a single specimen of the Channel blocks can be referred to Dartmoor. The minute characters of the Hey Tor and Lustleigh Cleave granites are well marked both positively and negatively. Three of each class of differences will probably suffice-e.g.: presence of fibrous tourmaline; of chloride inclusions in the quartzes; of soda felspar in the large potash felspars;-absence of hornblende; of dislocation of minerals; of any approach to gneissoid structure. Besides these there are others, but most granites not derived from Dartmoor will fail to meet one or other of the above tests.

(2) In the current number of the Geological Magazine (p. 177) Dr. Tilden's paper on Gases enclosed in Crystalline Rocks is shortly reviewed, and mention is made of hydrogen in the Peterhead granite. On seeing this I referred to some notes made in 1890 on a collection of granites which Mr. Teall had kindly lent me to study. Among these notes occur the following, under the heading "Pink Granite of Rubislaw" :- "A plane of fracture with fluid inclusions across another with only gas inclusions-order of sequence not made out. Rhombic negatives with bubbles. One negative hexagon with very active bubble. One patch of quartz full of hair-like inclusions and lines of bubbles: in one or two cases the hairs crossing the lines were distinctly divided in two, as seen with $\frac{1}{16}$. Could find no decided cubic crystal; any sort of crystal (in fluid inclusions) extremely rare. Bending in dark micas." Now it is not too much to 
say that the above granite is as distinct from the West Country granites as any two species can be. Now for the first time we learn that the Peterhead granite was consolidated in the presence of compressed hydrogen, just as we know that the Dartmoor rock crystallized out of fluids charged with salts. The conditions were different and the minute results are different-very. Those intersecting planes of fracture are significant enough. The Rubislaw granite was consolidated; then cracked and recemented; then cracked again and recemented; and the cements varied in the two cases. In the one, the cementing silica was charged with gas, in the other not apparently so. These facts are patent to anyone who will take adequate pains to see them. The explanations must be left to experts.

A. R. Hunt.

April 9, 1897.

\section{OBITUARY.}

\section{PROFESSOR EDWARD DRINKER COPE, A.M.,} FOR. CORR. GEOL. SOC. AND ZOOL. SOC. LOND,

BORN JULY 28, 1840.

DIED APRIL 12, 1897.

IT is with deep regret that we record the death of Professor E. D. Cope, the eminent palæontologist and comparative anatomist, late of 2100, Pine Street, Philadelphia, Pa., U.S.A. E. D. Cope, who was born at Philadelphia, July 28, 1840, studied in the University of Pennsylvania and worked at anatomy in Europe (in 1863-4). For the three succeeding years $(1864-7$ ) he filled the Chair of Professor of Natural Science in Haverford College, Philadelphia, and was for some years Curator and Corresponding Secretary of the Academy of Natural Sciences in that city. At the time of his death he held the Chair of Geology and Palæontology in the University of Pennsylvania. From 1871-7, he carried on explorations in the Cretaceous strata of Kansas; the Eocene of Wyoming; the Tertiary beds of Colorado. He also served on the U.S. Geological Survey in 1874 in New Mexico; in North Montana in 1875 ; in Oregon and Texas in 1877.

He has accumulated a collection of over 1000 species of extinct Vertebrata, and has made known at least 600 species new to science. Professor Cope was a voluminous writer, and his papers are published in the Proceedings of the scientific Societies of Philadelphia, and in the Reports of the U.S. Geological Survey of the 'Territories under Dr. F. V. Hayden and Captain Wheeler. Professor Cope was an advanced Evolutionist, and his contributions on this subject have been very numerous. He was the senior Editor of the "American Naturalist," a monthly journal which contains many of his original essays. He was a Foreign Correspondent of the Zoological and Geological Societies of London, and received the Bigsby Gold Medal in 1879 from the latter Society, in recognition of the genius and skill with which he had enriched the sciences of Comparative Anatomy and Palæontology, and the immense and varied work which he had achieved among the fussil Vertebrata. 